\title{
Service Waiting Time Behavior of Express Maintenance (EM) Program of PT. Dunia Barusa Banda Aceh
}

\section{(Perilaku Waktu Tunggu Layanan Program Express Maintenance (EM) PT. Dunia Barusa Cabang Banda Aceh)}

\author{
Samsul Anwar ${ }^{1 *}$, Tri Wahyudi ${ }^{2}$, Mutia Andriani ${ }^{3}$, Dinda Maulina ${ }^{4}$, Juraida Fitri ${ }^{5}$, \\ Raihan Nora ${ }^{6}$, Zulfazli $^{7}$
}

\begin{abstract}
Survival analysis is a statistical method that can be used to analyze duration time data of an event occurrence. This research uses secondary data from PT. Dunia Barusa branch Banda Aceh that collected from January to March 2017 which amounted to 107 data. The data is service waiting time (in minutes) of Express Maintenance (EM) program on sub section receptionist, service, final inspection, confirmation, technical complete, invoicing, customer notification and delivery. There are 4 functions analyzed, namely density probability function (PDF), cumulative distribution function (CDF), survival and hazard function. The study shows that the probability of a customer being in the waiting process of service tends to become smaller as the service waiting time become longer on each sub section of the EM program, as well as the probability to remain in the waiting process after the customer has been there within a certain period of time indicated by the survival function. The hazard function shows that the rate of a customer will be served instantaneously in the sub section receptionist, service, invoicing, customer notification and delivery changing over the time, while in the sub section of final inspection, technical complete and confirmation, the rates are constant over the time as high as $0.757,0.794$, and 3.336 respectively.
\end{abstract}

Keywords: $\quad$ CDF; express maintenance (EM); PDF; service waiting time;

survival and hazard function.

\begin{abstract}
Abstrak
Analisis survival adalah suatu metode statistik yang dapat digunakan untuk menganalisis data durasi waktu terjadinya suatu peristiwa. Penelitian ini menggunakan data sekunder dari PT. Dunia Barusa cabang Banda Aceh yang dihimpun sejak Januari - Maret 2017 yang berjumlah sebanyak 107 data. Data tersebut merupakan data waktu tunggu pelayanan (dalam satuan menit) program Express Maintenance (EM) pada sub bagian receptionist, service, final inspection, confirmation, technical complete, invoicing, customer notification dan delivery. Terdapat 4 fungsi yang dianalisis yaitu fungsi densitas peluang (PDF), fungsi distribusi kumulatif (CDF), fungsi survival dan fungsi hazard. Hasil penelitian menunjukkan bahwa peluang seorang customer berada dalam proses tunggu pelayanan cenderung menjadi semakin
\end{abstract}

* 1,2,3,4,5,6,7) Jurusan Statistika, Fakultas MIPA, Universitas Syiah Kuala, Jl. Syech Abdurrauf, Kopelma Darussalam, Syiah Kuala, Kota Banda Aceh, Aceh 23111.

Email: samsul.anwar@unsyiah.ac.id 


\title{
Samsul Anwar, Tri Wahyudi, Mutia Andriani, Dinda Maulina, Juraida Fitri, Raihan Nora, Zulfazli
}

\begin{abstract}
kecil seiring bertambahnya lama waktu tunggu pelayanan pada masing-masing sub bagian program EM, sama halnya dengan peluang untuk tetap berada pada proses tunggu setelah customer berada dalam proses tersebut dalam jangka waktu tertentu yang diindikasikan dengan fungsi survival. Fungsi hazard menunjukkan bahwa laju seorang customer akan dilayani seketika pada proses tunggu pelayanan program EM di sub bagian receptionist, service, invoicing, customer notification dan delivery berubah terhadap waktu, sedangkan pada sub bagian final inspection, technical complete dan confirmation justru memiliki nilai hazard yang tetap (konstan) terhadap waktu dengan nilai masing-masing secara berurut sebesar 0,757; 0,794 dan 3,336 .
\end{abstract}

Kata kunci: CDF; express maintenance (EM); fungsi survival dan hazard; PDF; waktu tunggu pelayanan.

\section{Pendahuluan}

Meningkatnya kompetisi yang mengarah pada pemenuhan tuntutan kebutuhan konsumen baik secara kualitas maupun kuantitas menyebabkan dunia usaha harus terus berjuang untuk meningkatkan pelayanan dan fleksibilitasnya untuk dapat beradaptasi dan berinovasi secara cepat dan tepat. Salah satu bagian penting pada sebuah perusahaan yang berhubungan langsung dengan pelanggan adalah bagian pelayanan. Penelitian Kuntari, dkk Pada tahun 2016 [1] menunjukkan bahwa terdapat pengaruh yang signifikan antara kualitas pelayanan dan kepuasan pelanggan, pengaruh yang signifikan antara kualitas pelayanan dan loyalitas pelanggan serta pengaruh yang signifikan antara kepuasan pelanggan dan loyalitas pelanggan pada Bengkel PT Astra International Tbk - Daihatsu Malang. Dengan mempertahankan kualitas pelayanan yang konsisten maka diharapkan pelanggan akan merasa puas dan tetap setia untuk menggunakan jasa perusahaan.

Kualitas pelayanan memiliki hubungan yang erat dengan waktu tunggu pelayanan. Waktu tunggu pelayanan yang terlalu lama dapat mengakibatkan pelanggan tidak mau berkunjung kembali di masa yang akan datang, dan hal ini akan menyebabkan kerugian secara implisit dan eksplisit bagi perusahaan penyedia layanan tersebut. Salah satu contoh proses tunggu dalam bidang pelayanan dapat ditemukan pada PT. Dunia Barusa cabang Banda Aceh. PT. Dunia Barusa merupakan salah satu perusahaan dealer mobil di bawah PT. Astra International Toyota Sales Operation di Provinsi Aceh yang memiliki beberapa outlet diantaranya Sigli, Meulaboh, Lhokseumawe dan Banda Aceh. PT. Dunia Barusa sebagai salah satu perusahaan di bawah bendera Toyota yang bergerak dalam bidang penjualan, administrasi dan pelayanan perbaikan mobil memiliki komitmen agar Toyota selalu selangkah lebih depan untuk membantu menghadirkan kehidupan yang lebih baik. PT. Dunia Barusa cabang Banda Aceh berusaha semaksimal mungkin dalam upaya meningkatkan mutu pelayanan agar dapat beroperasi secara optimal, baik dari segi kuantitas maupun kualitas. Salah satu program unggulan dalam pelayanan perbaikan (service) di PT. Dunia Barusa cabang Banda Aceh adalah Express Maintenance (EM). Proses tunggu dalam pelayanan EM diusahakan menjadi seminimum mungkin sehingga setiap pelanggan (customer) yang datang dapat segera dilayani tanpa harus menunggu dalam waktu yang lama untuk mendapatkan pelayan. Proses pelayanan service EM di PT. Dunia Barusa dibagi menjadi beberapa sub bagian kerja yaitu Receptionists, Service, Final Inspection, Konfirmasi, Technical Complete (Tec. Co.), Invoicing, Customer Notification, dan bagian Delivery. 


\section{Samsul Anwar, Tri Wahyudi, Mutia Andriani, Dinda Maulina, Juraida Fitri, Raihan Nora, Zulfazli}

Secara keseluruhan, program EM memiliki target waktu penyelesaian proses pengerjaan perawatan mobil selama 1 jam. Sebagai upaya dalam memenuhi target waktu tersebut, PT. Dunia Barusa cabang Banda Aceh terus melakukan upaya perbaikan proses kerja secara berkesinambungan sehingga dapat meminimalisir waktu tunggu pelayanan program EM tersebut. Dalam rangka melakukan evaluasi mengenai waktu tunggu program layanan EM tersebut, maka diperlukan penelitian serta evaluasi dari pihak eksternal perusahaan. Salah satu analisis statistik yang dapat digunakan untuk mengevaluasi waktu tunggu proses pelayanan program EM adalah dengan menggunakan metode Survival Analysis.

Dalam ilmu statistik, analisis survival adalah suatu metode statistik yang dapat digunakan untuk menganalisa data durasi waktu terjadinya suatu peristiwa atau kejadian. Kejadian dalam penelitian ini adalah dimulainya proses pelayanan pada sebuah sub bagian program EM. Analisis survival memberikan nilai peluang dalam bentuk fungsi densitas peluang (PDF), fungsi distribusi kumulatif (CDF), fungsi tahan hidup (survival) dan fungsi fungsi kegagalan (hazard) yang dapat menggambarkan perilaku waktu tunggu proses pelayanan pada setiap sub bagian kerja dalam program EM tersebut. Penelitian sejenis pernah dilakukan oleh Anwar, dkk pada tahun 2017 [2] yang menggunakan nilai PDF, CDF, survival dan hazard untuk melihat perilaku pengunjung UPT. Perpustakaan Universitas Syiah Kuala berdasarkan durasi waktu kunjungan mereka.

Berdasarkan latar belakang di atas, maka penelitian ini bertujuan untuk mengetahui perilaku waktu proses tunggu pelayanan program EM di PT. Dunia Barusa cabang Banda Aceh yang tergambarkan melalui nilai fungsi PDF, CDF, fungsi survival dan fungsi hazard. Hasil penelitian ini diharapkan dapat bermanfaat bagi PT. Dunia Barusa cabang Banda Aceh sebagai bahan evaluasi terhadap program layanan service terutama program Express Maintanance (EM).

\section{Kajian Literature}

\section{Analisis Survival}

Analisis survival atau lebih dikenal dengan analisis kelangsungan hidup merupakan analisis statistika khusus yang membantu menganalisis suatu kasus yang tidak dapat diselesaikan dengan analisis statistika pada umumnya. Analisis ini digunakan untuk kasus yang berkaitan dengan waktu dan lama waktu hingga terjadinya sebuah peristiwa tertentu dan kemungkinan adanya data tersensor yang merupakan karakteristik khas yang membedakannya dengan analisis statistik yang lain. Peristiwa yang diamati misalnya timbulnya suatu penyakit, kambuhnya penyakit, kesembuhan dari suatu penyakit dan kematian [3]. Selain berkaitan dengan bidang kesehatan, analisis survival juga dapat diterapkan dalam berbagai bidang lainnya seperti bidang pelayanan administrasi pemerintahan [4], bidang psikologis pendidikan [5], bidang pelayanan sosial keagamaan [6] serta bidang lainnya yang berkaitan dengan sebuah proses kejadian yang bergantung pada durasi waktu.

Analisis survival adalah suatu metode yang berhubungan dengan waktu, $T$, yang dimulai dari time origin atau start point sampai dengan terjadinya suatu kejadian khusus atau end point. Menurut Collett pada tahun 2003 [7], dalam analisis survival dibutuhkan beberapa hal sebagai berikut:

1) Waktu awal pencatatan (start point) yang didefinisikan dengan baik.

2) Waktu akhir pencatatan (end point) yang terdefinisi dengan baik untuk mengetahui status tersensor maupun tidak tersensor suatu data.

3) Skala waktu pengukuran yang jelas, misalnya dalam satuan hari, minggu atau tahun. 


\section{Samsul Anwar, Tri Wahyudi, Mutia Andriani, Dinda Maulina, Juraida Fitri, Raihan Nora, Zulfazli}

Terdapat 4 fungsi utama dalam analisis survival, yaitu: fungsi densitas peluang (PDF), fungsi distribusi kumulatif ( $C D F$ ), fungsi tahan hidup (fungsi survival), dan fungsi kegagalan (fungsi hazard).

\section{Fungsi Densitas Peluang dan Distribusi Kumulatif}

Fungsi densitas peluang menggambarkan peluang suatu unit atau individu mengalami sebuah kejadian (event) misalnya kegagalan dalam interval waktu $t$ sampai $t+\Delta$ yang dinotasikan dengan $f(t)$. Fungsi ini dirumuskan sebagai berikut:

$$
f(t)=\lim _{\Delta t \rightarrow 0} \frac{\mathrm{P}(t<T<t+\Delta t)}{\Delta \mathrm{t}}=\lim _{\Delta t \rightarrow 0} \frac{F(t+\Delta t)-F(t)}{\Delta \mathrm{t}}
$$

Menurut Lee dan Wang pada tahun 2003 [8], fungsi kepadatan peluang memiliki 2 sifat yaitu: $f(t)$ adalah fungsi non negatif dan luas daerah antar kurva kepadatan dengan sumbu $t$ sama dengan 1 atau $\int_{0}^{\infty} f(x) d x=1$. Menurut Zacks pada tahun 1992 [9], jika $T$ merupakan variabel acak positif pada interval $[0, \infty]$, maka $F(t)$ merupakan fungsi distribusi kumulatif kontinu dari $T$ dan didefinisikan sebagai peluang suatu individu mengalami kejadian kurang dari sama dengan waktu $t$, yaitu,

$$
F(t)=P(T \leq t)=\int_{0}^{t} f(x) d x
$$

Sehingga diperoleh:

$$
f(t)=\frac{d(F(t))}{d t}
$$

\section{Fungsi Survival}

Menurut Zacks pada tahun 1992 [9], fungsi survival $(s(t))$ didefinisikan sebagai peluang seorang individu atau sebuah unit dapat bertahan atau berfungsi secara normal sampai dengan waktu $t(t>0)$ yang dapat ditulis dalam persamaan matematis sebagai berikut:

$$
\mathrm{S}(t)=P(T \geq t)=\int_{t}^{\infty} f(t) d t
$$

Fungsi survival juga dapat dinyatakan dalam bentuk distribusi kumulatif dengan

$$
\begin{aligned}
\mathrm{S}(t) & =1-P(T \leq t) \\
& =1-F(t)
\end{aligned}
$$

Selanjutnya, hubungan antara fungsi densitas peluang, fungsi distribusi kumulatif dan fungsi survival dapat ditulis sebagai berikut:

$$
\begin{aligned}
F(t) & =1-\mathrm{S}(t) \\
& =\frac{d(F(t))}{d t}=\frac{d(1-s(t))}{d t} \\
& =F^{\prime}(t)=f(t)=-S^{\prime}(t)
\end{aligned}
$$

\section{Fungsi Hazard}

Menurut Zacks pada tahun 1992 [9], fungsi hazard $(h(t))$ didefinisikan sebagai kelajuan suatu individu atau unit mengalami kejadian dalam interval waktu dari $t$ sampai $t+\Delta t$ dengan syarat individu atau unit tersebut masih bertahan atau berfungsi secara normal sampai dengan waktu $t$, atau secara matematis dapat dinyatakan sebagai berikut: 


\section{Samsul Anwar, Tri Wahyudi, Mutia Andriani, Dinda Maulina, Juraida Fitri, Raihan Nora, Zulfazli}

$$
h(t)=\lim _{\Delta t \rightarrow 0} \frac{\mathrm{P}(t<T<t+\Delta t \mid T \geq t)}{\Delta t}=\frac{f(t)}{(1-F(t))}=\frac{f(t)}{S(t)}
$$

\section{Distribusi Peluang}

Terdapat tiga buah distribusi peluang yang digunakan dan dianalisis dalam penelitian ini, yaitu distribusi Exponential, Weibull dan Log normal.

\section{Distribusi Exponential}

Distribusi exponential merupakan salah satu distribusi peluang yang sering dipakai dalam analisis survival. Distribusi exponential memiliki fungsi hazard yang konstan terhadap waktu. Parameter yang digunakan dalam distribusi exponential adalah rate $(\lambda)$. Fungsi-fungsi dasar dalam analisis survival dari distribusi exponential ditampilkan pada Tabel 1 [10].

Tabel 1. Fungsi Survival untuk Distribusi Exponential

\begin{tabular}{cccc}
\hline $\boldsymbol{f}(\boldsymbol{t})$ & $\boldsymbol{F}(\boldsymbol{t})$ & $\boldsymbol{S}(\boldsymbol{t})$ & $\boldsymbol{h}(\boldsymbol{t})$ \\
\hline$\lambda e^{-\lambda t}$ & $1-e^{-\lambda t}$ & $e^{-\lambda t}$ & $\lambda$ \\
\hline Dimana: $t>0$ dan $\lambda>0$ & & &
\end{tabular}

\section{Distribusi Weibull}

Distribusi weibull adalah distribusi yang paling banyak digunakan untuk data waktu tunggu dalam analisis survival karena distribusi ini dapat digunakan untuk hazard yang meningkat maupun menurun. Terdapat dua buah parameter dalam distribusi weibull, yaitu parameter shape (bentuk) dan scale (skala). Parameter shape dan scale secara berurutan disimbolkan dengan $\alpha$ dan $\lambda$. Tabel 2 menyajikan fungsi-fungsi dasar dalam analisis survival dari distribusi weibull [10].

Tabel 2. Fungsi Survival untuk Distribusi Weibull

\begin{tabular}{cccc}
\hline $\boldsymbol{f}(\boldsymbol{t})$ & $\boldsymbol{F}(\boldsymbol{t})$ & $\boldsymbol{S}(\boldsymbol{t})$ & $\boldsymbol{h}(\boldsymbol{t})$ \\
\hline$\alpha \lambda^{\alpha} t^{\alpha-1} e^{-(\lambda t)^{\alpha}}$ & $1-e^{-(\lambda t)^{\alpha}}$ & $e^{-(\lambda t)^{\alpha}}$ & $\alpha \lambda^{\alpha} t^{\alpha-1}$ \\
\hline
\end{tabular}

Dimana: $t>0 ; \lambda>0$ dan $\alpha>0$

\section{Distribusi Log normal}

Distribusi log normal juga memiliki dua buah parameter yaitu parameter mean yang disimbolkan dengan $v$ dan parameter standar deviation yang disimbolkan dengan $\tau$. Tabel 3 menyajikan fungsi-fungsi dasar dalam analisis survival dari distribusi log normal [10].

Tabel 3. Fungsi Survival untuk Distribusi Log Normal

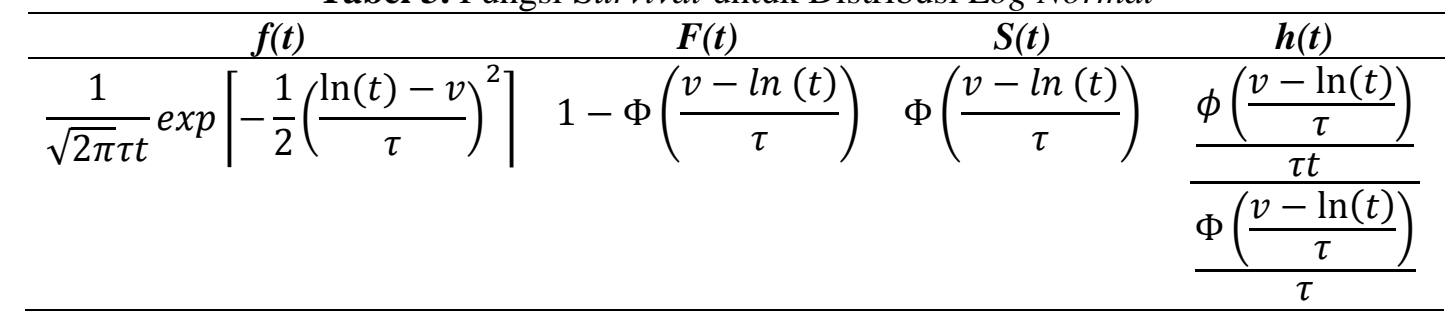




\section{Samsul Anwar, Tri Wahyudi, Mutia Andriani, Dinda Maulina, Juraida Fitri, Raihan Nora, Zulfazli}

Dimana $\Phi($.$) adalah fungsi distribusi dari standar normal dan \phi($.$) adalah densitas peluang dari$ standar normal.

\section{Penentuan Estimasi Parameter (Maximum Likelihood Estimation)}

Maximum likelihood estimation (MLE) merupakan salah satu metode yang dapat digunakan untuk mengestimasi nilai parameter $(\theta)$ dari sebuah distribusi peluang. Estimasi parameter tersebut diperoleh dengan memaksimalkan nilai logaritma natural dari fungsi likelihood. Fungsi logaritma natural dari fungsi likelihood tersebut diturunkan secara parsial terhadap masing-masing parameter $(\theta)$ untuk mendapatkan nilai estimasi parameternya $(\hat{\theta})$.

Menurut Hogg dan Tanis pada tahun 2010 [11], fungsi likelihood dari $n$ variabel random $X_{1}, X_{2}, X_{3}, \ldots . X_{n}$ yang bergantung pada nilai parameter $\theta$, didefinisikan sebagai fungsi kepadatan peluang bersama dari $n$ variabel random tersebut. Secara matematis dapat ditulis dalam persamaan:

$$
\begin{aligned}
L(\theta) & =f\left(x_{1} ; \theta\right) f\left(x_{2} ; \theta\right) f\left(x_{3} ; \theta\right) \ldots f\left(x_{n} ; \theta\right) \\
& =\prod_{i=1}^{n} f\left(x_{i} ; \theta\right)
\end{aligned}
$$

Dengan demikian, estimasi parameter $\hat{\theta}$ dengan menggunakan MLE dapat diperoleh dengan menyelesaikan persamaan berikut:

$$
\frac{d[\ln L(\theta)]}{d \theta}=0
$$

\section{Kriteria Pemilihan Distribusi} berikut:

1. Akaike Information Criterion (AIC)

Menurut Stasinopoulos et al. pada tahun 2007 [12], Akaike Information Criterion (AIC) adalah sebuah indikator yang dapat digunakan untuk menentukan model atau distribusi terbaik yang ditemukan oleh Akaike. Besarnya nilai AIC ditentukan dengan persamaan (10).

$$
\mathrm{AIC}=-2 l(\hat{\theta})+2 d f
$$

dengan $l(\hat{\theta})$ adalah fungsi log likelihood dan $d f$ (degree of freedom) adalah total derajat bebas yang digunakan dalam model. Distribusi peluang terbaik adalah distribusi yang memiliki nilai AIC terkecil.

\section{Bayesian Information Criterion (BIC)}

Bayesian Information Criterion (BIC) dalam ilmu statistika juga dikenal dengan Schwarz Bayesian Criterion (SBC). Menurut Stasinopoulos et al. pada tahun 2007 [12], besarnya nilai BIC ditentukan melalui persamaan (11)

$$
\mathrm{BIC}=-2 l(\hat{\theta})+(\log (n) d f)
$$

dimana $n$ merupakan banyak data. Sama halnya dengan indikator AIC, distribusi peluang terbaik juga dilihat berdasarkan nilai BIC terkecil.

\section{Jenis Pekerjaan Perawatan di PT. Dunia Barusa Cabang Banda Aceh}

Express Maintenance (EM) merupakan salah satu program pelayanan service unggulan yang diberikan oleh PT. Dunia Barusa dalam hal perawatan express. Program ini memiliki target 


\section{Samsul Anwar, Tri Wahyudi, Mutia Andriani, Dinda Maulina, Juraida Fitri, Raihan Nora, Zulfazli}

waktu proses pengerjaan perawatan mobil kurang dari satu jam. Terdapat delapan sub bagian kerja pada program pelayanan EM yaitu: Recepcionists, Service, Final Inspection, Confirmation, Technical Complete (Tec. Co.), Invoicing, Customer Notification, dan Delivery. Berikut merupakan penjelasan singkat dari masing-masing sub bagian kerja program EM.

1. Recepcionists

Recepcionists merupakan proses registrasi atau pendaftaran program pelayanan EM.

2. Service

Service merupakan proses kerja perawatan atau perbaikan mobil customer.

3. Final Inspection

Final inspection merupakan proses kegiatan pengecekan akhir pada mobil customer yang ditangani.

4. Confirmation

Confirmation merupakan proses pemberitahuan dari bidang service kepada receptionist bahwa pengerjaan sudah selesai.

5. Technical complete (Tec.co.)

Technical complete atau yang disingkat dengan Tec.co. merupakan status pengerjaan kendaraan yang dinyatakan ketika sudah benar-benar selesai.

6. Invoicing

Invoicing merupakan proses pengisian dokumen-dokumen administrasi termasuk masalah pembayaran jasa pelayanan EM.

7. Customer notification

Customer notification merupakan proses pemberitahuan kepada customer bahwa mobil yang ditangani sudah selesai dilakukan perawatan atau perbaikan. Proses tersebut biasanya dilakukan melalui sambungan telepon.

8. Delivery

Delivery merupakan proses penyerahan mobil yang telah ditangani dalam program EM kepada customer pemiliknya.

\section{Metode Penelitian}

Data yang digunakan dalam penelitian ini adalah data sekunder yang diperoleh dari PT. Dunia Barusa cabang Banda Aceh yang dihimpun mulai dari bulan Januari - Maret 2017. Total sampel yang digunakan pada penelitian ini adalah sebanyak 107 unit. Data tersebut merupakan data waktu tunggu proses pelayanan (dalam satuan menit) program Express Maintenance (EM) di PT. Dunia Barusa cabang Banda Aceh pada sub bagian receptionist, service, final inspection, confirmation, technical complete, invoicing, customer notification dan delivery. Defenisi variabel waktu tunggu proses pelayanan program EM adalah lamanya waktu yang dihabiskan seorang customer untuk menunggu sampai mendapatkan pelayanan pada sebuah sub bagian kerja program EM di PT. Dunia Barusa cabang Banda Aceh. Adapun langkah-langkah analisis yang dilakukan dalam penelitian ini adalah sebagai berikut:

1. Melakukan analisis deskriptif untuk mengetahui karakteristik dari data lama waktu tunggu pelayanan program EM di PT. Dunia Barusa cabang Banda Aceh yang disajikan dalam summary dan plot.

2. Melakukan analisis inferensia untuk membuat kesimpulan dari data lama waktu tunggu pelayanan program EM di PT. Dunia Barusa cabang Banda Aceh dengan menggunakan 


\section{Samsul Anwar, Tri Wahyudi, Mutia Andriani, Dinda Maulina, Juraida Fitri, Raihan Nora, Zulfazli}

analisis survival yang terdiri dari fungsi PDF, CDF, survival dan hazard. Adapun langkahlangkah kerja yang dilakukan adalah sebagai berikut:

a. Menentukan distribusi peluang data dari variabel lama waktu tunggu pelayanan pada setiap sub bagian kerja program EM di PT. Dunia Barusa cabang Banda Aceh dengan menggunakan metode Maximum likelihood Estimation (MLE) berdasarkan persamaan (8) dan (9) dengan menggunakan package Generalized Additive Models for Location Scale and Shape (GAMLSS) pada aplikasi software $R$. Kriteria nilai AIC dan BIC pada persamaan (10) dan (11) digunakan sebagai indikator dalam penentuan distribusi peluang masing-masing sub bagian kerja. Estimasi parameter dari masing-masing distribusi juga dilakukan pada tahap ini.

b. Menganalisis perilaku waktu tunggu pelayanan pada kedelapan sub bagian program EM PT. Dunia Barusa cabang Banda Aceh yang tergambarkan melalui nilai fungsi densitas peluang (PDF), fungsi distribusi kumulatif (CDF), fungsi survival dan hazard yang dihitung berdasarkan distribusi peluang yang bersesuaian pada tahap sebelumnya.

\section{Hasil dan Pembahasan}

\section{Analisis Deskriptif}

Tahap awal dalam menganalisa sebuah data adalah dengan menggambarkan secara umum karakteristik dari data yang diamati tersebut. Penyajian data pada analisis deskriptif ini menggunakan summary statistik dan plot guna memberikan informasi tentang karakteristik dan kecenderungan data. Nilai statistik deskriptif data penelitian untuk semua sub bagian kerja program EM ditampilkan pada Tabel 4.

Tabel 4. Statistik Deskriptif Data Penelitian

\begin{tabular}{lrrrrrr}
\hline \multicolumn{1}{c}{ Variabel Amatan } & Min & Mak & Mean & $\mathbf{Q}_{\mathbf{1}}$ & Median & $\mathbf{Q}_{\mathbf{3}}$ \\
\hline Receptionist & $<1,0$ & 102,0 & 9,85 & 3,0 & 5,0 & 9,5 \\
Service & 1,0 & 170,0 & 31,89 & 3,0 & 18,0 & 41,0 \\
Final Inspection & $<1,0$ & 6,0 & 0,75 & 1,0 & $<1,0$ & 1,0 \\
Confirmation & $<1,0$ & 24,0 & 3,36 & 2,0 & 2,0 & 2,0 \\
Technical Complete & $<1,0$ & 3,0 & 0,79 & $<1,0$ & 1,0 & 1,0 \\
Invoicing & $<1,0$ & 44,0 & 4,24 & 1,0 & 1,0 & 2,5 \\
Customer Notification & $<1,0$ & 32,0 & 4,51 & 1,0 & 2,0 & 5,0 \\
Delivery & 1,0 & 313,0 & 17,80 & 5,0 & 17,8 & 12,0 \\
\hline
\end{tabular}

Tabel 4 menampilkan nilai minimum, maksimum, mean, kuantil1 $\left(\mathrm{Q}_{1}\right)$, median dan kuantil $3\left(\mathrm{Q}_{3}\right)$ dari setiap data lama waktu tunggu sub bagian pelayanan program EM di PT. Dunia Barusa cabang Banda Aceh. Secara keseluruhan, data yang digunakan dalam penelitian ini adalah sebanyak 856 data waktu tunggu pelayanan di 8 sub bagian kerja program EM di PT. Dunia Barusa cabang Banda Aceh, dimana masing-masing sub bagian kerja terdiri atas 107 data. Berdasarkan Tabel 4, terlihat bahwa rata-rata lama waktu tunggu pelayanan program EM yang paling besar adalah selama 31,89 menit yaitu pada sub bagian service dengan nilai median selama 18 menit. Sekitar $25 \%$ customer hanya membutuhkan waktu tunggu selama 3 menit 


\section{Samsul Anwar, Tri Wahyudi, Mutia Andriani, Dinda Maulina, Juraida Fitri, Raihan Nora, Zulfazli}

untuk mendapatkan pelayanan pada sub bagian service dan $75 \%$ dari total coustomer membutuhkan waktu tunggu selama 41 menit. Sedangkan rata-rata lama waktu tunggu pelayanan program EM yang paling sedikit adalah selama 0,75 menit ( 45 detik) yaitu pada sub bagian final inspection dan 0,79 menit (47 detik) pada sub bagian technical complete. Selain itu, terlihat bahwa perbandingan nilai mean dan median yang diperoleh dari sub bagian receptionist, service, confirmation, invoicing, dan customer notification jauh berbeda. Hal ini mungkin dikarenakan adanya data pencilan yang bernilai jauh dari data lainnya seperti yang terlihat melalui nilai maksimum yang terlalu besar jika dibandingkan dengan nilai rata-ratanya.

Variabel yang menjadi fokus dalam penelitian ini adalah lama waktu tunggu pelayanan program EM di PT. Dunia Barusa cabang Banda Aceh pada sub bagian receptionist, service, final inspection, confirmation, technical complete, invoicing, customer notification dan delivery. Pada langkah awal, data lama waktu tunggu pelayanan yang dihimpun untuk masing-masing sub bagian kerja program EM diurutkan dari yang bernilai paling kecil sampai nilai yang paling besar (order statistik) untuk melihat gambaran lamanya waktu tunggu pelayanan program EM di PT. Dunia Barusa cabang Banda Aceh. Plot sebaran data lama waktu tunggu pelayanan program EM di PT. Dunia Barusa untuk masing-masing sub bagian dapat dilihat pada Gambar 1.
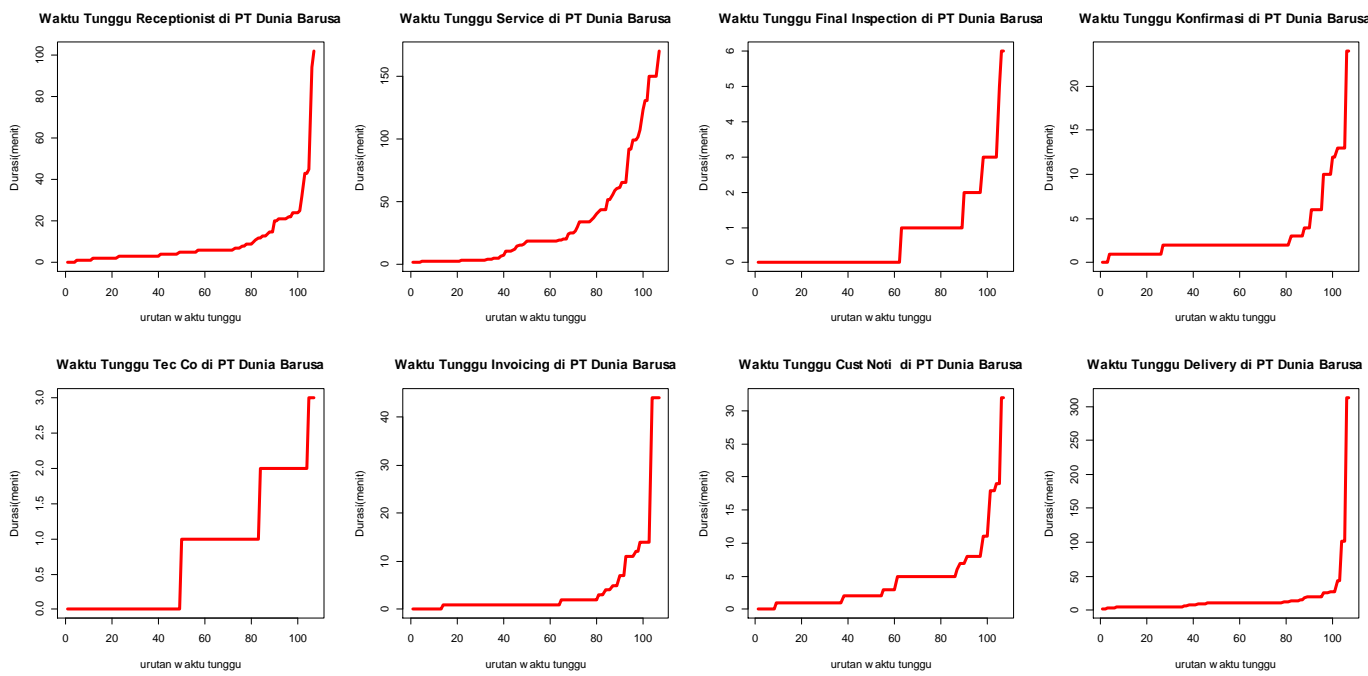

Gambar 1. Plot Data Lama Waktu Tunggu Pelayanan Program EM PT. Dunia Barusa Cabang Banda Aceh

\section{Analisis Inferensia}

Analisis inferensia merupakan proses analisis data secara lebih mendalam yang dilakukan untuk membuat penarikan kesimpulan dari data lama waktu tunggu pelayanan program EM di PT. Dunia Barusa cabang Banda Aceh. Analisis inferensia dalam penelitian ini dibagi menjadi 2 bagian utama. Pertama, penentuan distribusi peluang yang paling sesuai dengan data lama waktu tunggu beserta estimasi parameternya dengan menggunakan metode MLE berdasarkan persamaan (8) dan (9). Kedua, analisis perilaku waktu tunggu pelayanan program EM di PT. Dunia Barusa cabang Banda Aceh yang dilihat melalui keempat fungsi dasar dalam 


\section{Samsul Anwar, Tri Wahyudi, Mutia Andriani, Dinda Maulina, Juraida Fitri, Raihan Nora, Zulfazli}

analisis survival yaitu fungsi PDF, CDF, survival dan hazard yang bersesuaian untuk kedelapan sub bagian program EM PT. Dunia Barusa cabang Banda Aceh.

\section{Menentukan Distribusi Peluang Data Waktu Tunggu Pelayanan}

Penentuan distribusi peluang data waktu tunggu pelayanan pada sub bagian receptionist, service, final inspection, confirmation, technical complete, invoicing, customer notification dan delivery pada program EM di PT. Dunia Barusa cabang Banda Aceh dilakukan dengan menggunakan metode MLE yang memiliki nilai AIC (persamaan 10) dan BIC (persamaan 11) minimum. Pada penelitian ini, terdapat 7 distribusi peluang yang diujikan yaitu (a) distribusi Normal, (b) Geometri, (c) Logistic, (d) Exponential, (e) Weibull, (f) Log normal dan (g) Poisson. Tabel 5 menyajikan nilai AIC dan BIC dari masing-masing distribusi peluang yang diujikan untuk kedelapan sub bagian kerja pada program EM PT. Dunia Barusa cabang Banda Aceh.

Tabel 5. Nilai AIC dan BIC Pengujian Distribusi Peluang Waktu Tunggu Pelayanan Program EM PT. Dunia Barusa Cabang Banda Aceh

\begin{tabular}{|c|c|c|c|c|c|c|c|c|c|}
\hline \multirow{2}{*}{$\begin{array}{l}\text { Distribusi } \\
\text { Peluang }\end{array}$} & \multirow[b]{2}{*}{ Kriteria } & \multicolumn{8}{|c|}{ Sub Bagian Kerja Program EM } \\
\hline & & Receptionist & Service & $\begin{array}{c}\text { Final } \\
\text { Inspection }\end{array}$ & Konfirmasi & $\begin{array}{l}\text { Tec. } \\
\text { Co. }\end{array}$ & Invoicing & $\begin{array}{c}\text { Customer } \\
\text { Notification }\end{array}$ & Delivery \\
\hline \multirow{2}{*}{ Normal } & AIC & 889,56 & 1100,94 & 349,13 & 612,60 & 273,09 & 769,04 & 676,36 & 1113,57 \\
\hline & BIC & 894,90 & 1106,28 & 354,48 & 617,95 & 278,44 & 774,39 & 681,70 & 1118,91 \\
\hline \multirow{2}{*}{ Geometri } & AIC & 1770,34 & 960,23 & 259,01 & 503,12 & 265,64 & 548,72 & 560,66 & 838,94 \\
\hline & BIC & 1773,01 & 962,91 & 261,68 & 505,79 & 268,31 & 551,40 & 563,33 & 840,76 \\
\hline \multirow{2}{*}{ Logistic } & AIC & 823,13 & 1083,76 & 323,97 & 563,09 & 279,23 & 695,56 & 634,77 & 964,33 \\
\hline & BIC & 828,48 & 1089,10 & 329,31 & 568,34 & 284,57 & 700,91 & 640,12 & 969,68 \\
\hline \multirow{2}{*}{ Eksponensial } & AIC & 705,52 & 956,91 & 156,44 & 437,85 & 166,75 & 525,28 & 538,53 & 832,19 \\
\hline & BIC & 708,20 & 959,58 & 159,11 & 476,52 & 169,42 & 527,96 & 541,21 & 834,86 \\
\hline \multirow{2}{*}{ Weibull } & AIC & 691,66 & 944,05 & 452,10 & 475,07 & 233,52 & 411,43 & 516,52 & 824,19 \\
\hline & BIC & 697,09 & 949,40 & 446,75 & 480,41 & 228,17 & 416,77 & 521,86 & 829,54 \\
\hline \multirow{2}{*}{ Lognormal } & AIC & 773,12 & 938,78 & 463,57 & 558,05 & 225,80 & 474,99 & 607,54 & $\mathbf{7 5 8 , 7 3}$ \\
\hline & BIC & 778,47 & 944,12 & 458,22 & 563,40 & 220,45 & 480,34 & 512,88 & 764,08 \\
\hline \multirow{2}{*}{ Poisson } & AIC & 1770,34 & 4973,93 & 281,16 & 638,64 & 250,99 & 1203,99 & 825,26 & 4040,84 \\
\hline & BIC & 1773,01 & 4976,61 & 283,38 & 641,31 & 253,66 & 1206,66 & 828,49 & 4043,51 \\
\hline
\end{tabular}

Berdasarkan Tabel 5 diketahui bahwa distribusi peluang yang sesuai dengan kriteria nilai AIC dan BIC minimum untuk kedelapan sub bagian kerja program EM antara lain adalah distribusi weibull, log normal dan exponential. Variabel waktu tunggu pelayanan yang mengikuti distribusi weibull adalah receptionist, invoicing dan customer notification. Variabel waktu tunggu pelayanan yang mengikuti distribusi log normal adalah service dan delivery. Sedangkan variabel waktu tunggu pelayanan yang mengikuti distribusi exponential adalah technical complete, final inspection dan confirmation. Estimasi nilai parameter dari seluruh distribusi peluang yang bersesuaian dengan masing-masing sub bagian kerja program EM disajikan pada Tabel 6.

Tabel 6 menunjukkan beberapa parameter penting dari masing-masing distribusi peluang. Parameter tersebut antara lain adalah shape dan scale untuk distribusi weibull, rate untuk 


\section{Samsul Anwar, Tri Wahyudi, Mutia Andriani, Dinda Maulina, Juraida Fitri, Raihan Nora, Zulfazli}

distribusi exponential serta mean dan standard deviation untuk distribusi log normal. Parameter tersebut digunakan dalam melakukan analisa perilaku proses tunggu pelayanan program EM di PT. Dunia Barusa cabang Banda Aceh yang tergambar melalui keempat fungsi dasar dalam analisis survival.

Tabel 6. Estimasi Parameter dengan Metode Maximum Likelihood

\begin{tabular}{llll}
\hline Variabel Amatan & Distribusi Peluang & $\begin{array}{l}\text { Jenis } \\
\text { Parameter }\end{array}$ & $\begin{array}{l}\text { Nilai } \\
\text { Parameter }\end{array}$ \\
\hline Receptionist & Weibull & Shape & 0,7659 \\
& & Scale & 8,4225 \\
Service & Log Normal & Mean & 2,5725 \\
& & SD & 1,4573 \\
Final Inspection & Exponential & Rate & 1,3209 \\
Confirmation & Exponential & Rate & 0,2997 \\
Technical Complete & Exponential & Rate & 1,2588 \\
Invoicing & Weibull & Shape & 0,5031 \\
& & Scale & 2,3889 \\
Customer Notification & Weibull & Shape & 0,7016 \\
& & Scale & 3,7975 \\
Delivery & Log normal & Mean & 2,2510 \\
& & SD & 0,8666 \\
\hline
\end{tabular}

2. Analisis Perilaku Waktu Tunggu Pelayananan Program EM PT. Dunia Barusa Cabang Banda Aceh

Setelah nilai parameter dari masing-masing distribusi peluang diestimasi, maka fungsi densitas peluang (PDF), fungsi distribusi kumulatif (CDF), fungsi survival dan hazard dapat dihitung dengan persamaan yang terdapat pada Tabel 1,2 dan 3. Perilaku proses waktu tunggu pelayanan program EM di PT. Dunia Barusa cabang Banda Aceh dapat dilihat melalui fungsi probabilitas, survival, dan hazard dari data lama waktu tunggu pelayanan program EM di PT. Dunia Barusa cabang Banda Aceh. Nilai dari fungsi densitas peluang (PDF) dari data lama waktu proses tunggu di kedelapan sub bagian pelayanan program EM di PT. Dunia Barusa cabang Banda Aceh ditampilkan secara visual pada Gambar 2. 


\section{Samsul Anwar, Tri Wahyudi, Mutia Andriani, Dinda Maulina, Juraida Fitri, Raihan Nora, Zulfazli}
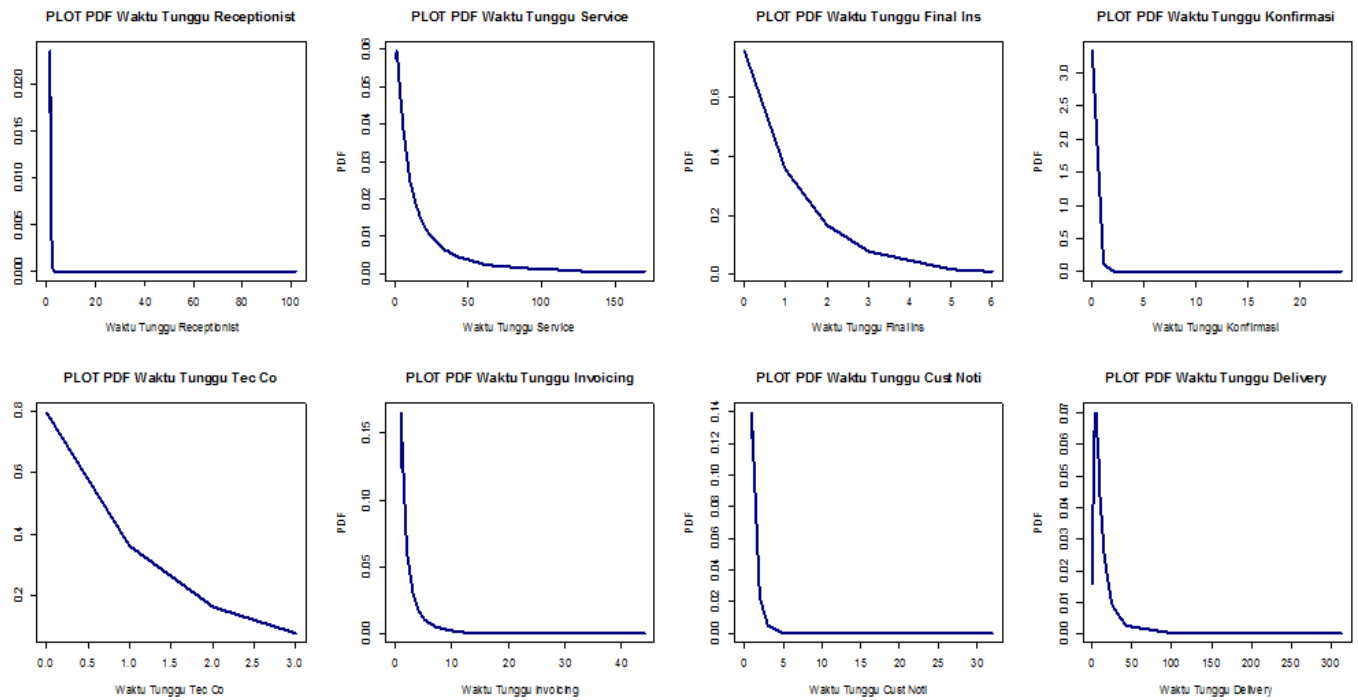

Gambar 2. Plot Nilai PDF Data Lama Waktu Tunggu Pelayanan Program EM

PT. Dunia Barusa Cabang Banda Aceh

Fungsi PDF menggambarkan besarnya peluang seorang customer akan mendapatkan pelayanan setelah menunggu selama waktu $t$ menit. Nilai dari fungsi PDF yang ditampilkan dalam bentuk grafik tersebut dapat menggambarkan secara lebih jelas mengenai perilaku proses tunggu pelayanan program EM PT. Dunia Barusa cabang Banda Aceh berdasarkan lama waktu tunggu pelayanan yang diberikan. Secara umum, kecenderungan atau trend dari fungsi PDF untuk kedelapan sub bagian pelayanan program EM terbagi menjadi 3 pola, pertama menurun secara signifikan, kedua menurun secara eksponensial dan ketiga meningkat sampai titik tertentu lalu kemudian menurun kembali secara eksponensial. Fungsi PDF yang menurun secara signifikan berada pada sub bagian receptionist, invoicing, confirmation dan customer notification. Peluang seorang customer untuk mendapatkan pelayanan pada keempat sub bagian tersebut cenderung menjadi semakin kecil secara drastis setelah beberapa waktu berada pada proses tunggu dan kemudian peluang tersebut cenderung menuju 0 dalam jangka waktu sesaat setelahnya. Dengan kata lain, customer pada keempat sub bagian tersebut berpeluang besar untuk dilayani dengan waktu tunggu yang relatif singkat. Sub bagian program EM yang memiliki trend penurunan peluang customer mendapatkan pelayanan secara eksponensial adalah pada sub bagian final inspection dan technical complete. Dengan demikian, peluang seorang customer mendapatkan pelayanan pada kedua sub bagian tersebut menurun secara berlahan (eksponensial) seiring bertambahnya lama waktu tunggunya. Sedangkan peluang seorang customer mendapatkan pelayanan pada sub bagian service dan delivery cenderung mengalami peningkatan yaitu sampai pada menit ke-2 untuk sub bagian service dan sampai pada menit ke-5 untuk sub bagian delivery. Setelah waktu tersebut, peluang customer untuk mendapatkan pelayanan akan menurun secara eksponsial.

Sementara itu, fungsi distribusi kumulatif (CDF) dari data lama waktu tunggu pelayanan memiliki perilaku yang terbalik jika dibandingkan dengan PDF. Peluang kumulatif tersebut cenderung mengalami kenaikan terhadap waktu. Hal ini dikarenakan nilai CDF merupakan akumulasi peluang dari titik awal (kedatangan) sampai dengan waktu $t$ menit yang dihabiskan dalam proses tunggu pelayanan program EM di PT. Dunia Barusa cabang Banda Aceh. Dengan kata lain, $\mathrm{CDF}$ adalah peluang proses tunggu pelayanan program EM dari menit awal kedatangan 


\section{Samsul Anwar, Tri Wahyudi, Mutia Andriani, Dinda Maulina, Juraida Fitri, Raihan Nora, Zulfazli}

sampai dengan waktu tertentu $t$ menit. Gambar 3 menampilkan visualisasi peluang CDF dalam bentuk grafik utuk semua sub bagian pelayanan program EM di PT. Dunia Barusa cabang Banda Aceh.
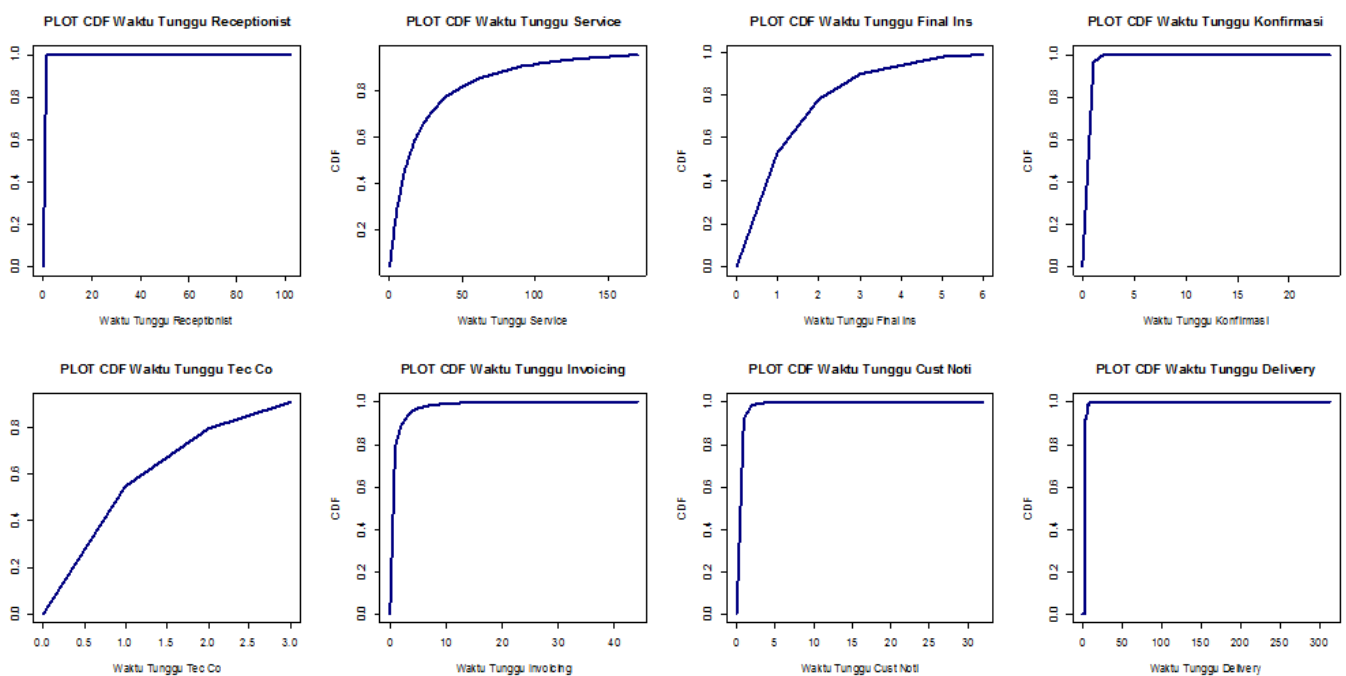

Gambar 3. Plot Nilai CDF Data Lama Waktu Tunggu Pelayanan Program EM PT. Dunia Barusa Cabang Banda Aceh

Secara umum, peluang CDF cederung mendekati 1 seiring bertambah lamanya waktu tunggu pada setiap sub bagian program EM sesuai dengan trend kenaikan masing-masing sub bagian seperti yang ditampilkan pada Gambar 3. Sebagai contoh, peluang seorang customer berada pada proses tunggu yang tidak melebihi 4 menit pada sub bagian receptionist adalah sebesar 0.99999, sedangkan peluang customer berada pada proses tunggu pelayanan sub bagian service untuk jangka waktu yang sama adalah sebesar 0,20783. Gambar 3 juga menunjukkan bahwa perilaku fungsi CDF pada proses tunggu pelayanan program EM di PT. Dunia Barusa cabang Banda Aceh pada sub bagian receptionist, confirmation, invoicing, customer notification dan delivery memiliki bentuk yang relatif mirip yaitu adanya peningkatan peluang secara tajam pada menit-menit awal waktu tunggu (0-5 menit). Sedangkan sub bagian service, final inspection dan technical complete memiliki bentuk yang relatif mirip berupa adanya kenaikan peluang CDF secara eksponensial. Semakin kecil nilai peluang kumulatif tersebut, maka akan semakin sedikit lama waktu tunggu pelayanan program EM di PT.Dunia Barusa cabang Banda Aceh. Sebaliknya, semakin besar nilai kumulatif maka semakin besar lama waktu tunggu pelayanan program EM di PT. Dunia Barusa cabang Banda Aceh.

Selain fungsi PDF dan CDF, fungsi survival juga sangat penting untuk dianalisis. Nilai fungsi survival dari data lama waktu tunggu pada semua sub bagian pelayanan program EM di PT. Dunia Barusa cabang Banda Aceh ditampilkan pada Gambar 4. 


\section{Samsul Anwar, Tri Wahyudi, Mutia Andriani, Dinda Maulina, Juraida Fitri, Raihan Nora, Zulfazli}
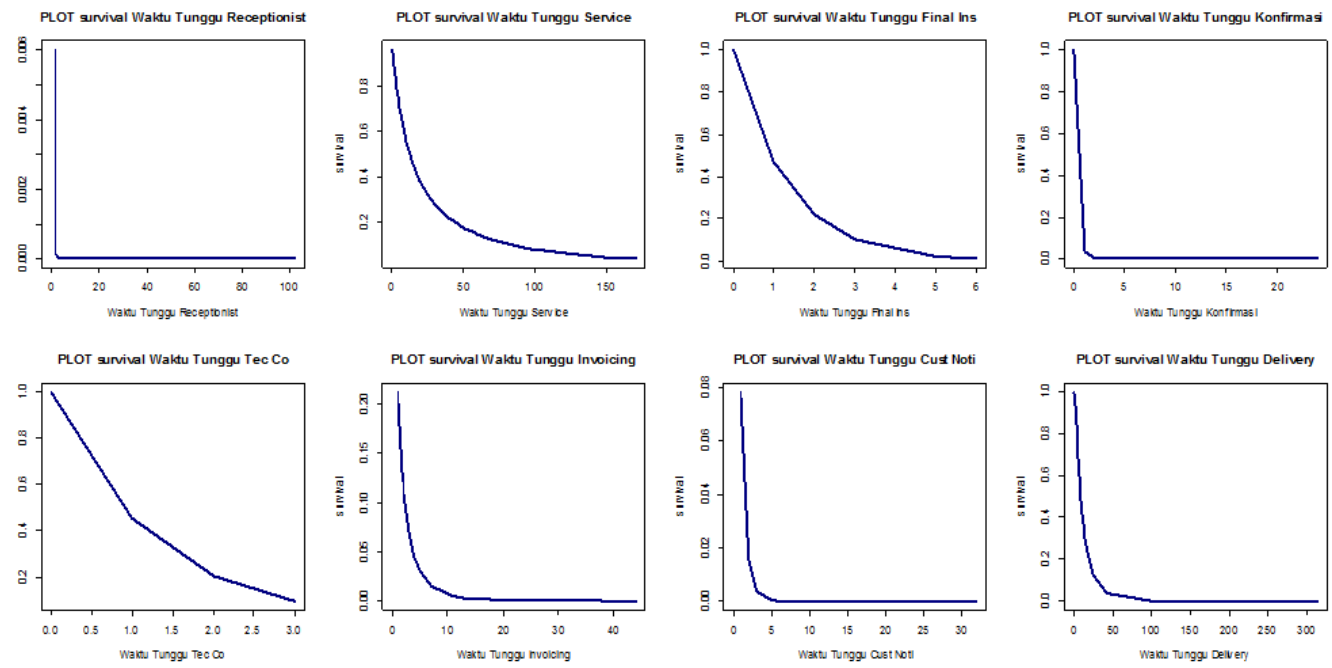

Gambar 4. Plot Nilai Survival Data Lama Waktu Tunggu Pelayanan Program EM

PT. Dunia Barusa Cabang Banda Aceh

Fungsi survival pada waktu $t$ mengambarkan peluang seorang customer tetap berada dalam proses tunggu pelayanan program EM setelah customer tersebut menunggu selama waktu $t$ menit. Gambar 4 menunjukkan bahwa fungsi survival memiliki perilaku yang mirip dengan perilaku fungsi PDF. Secara umum terdapat dua kecenderungan perilaku fungsi survival, pertama nilai peluang fungsi survival menurun secara signifikan pada awal waktu tunggu dan kedua nilai peluang fungsi survival menurun secara eksponensial seiring bertambah lamanya waktu tunggu. Sub bagian pelayanan program EM yang memiliki perilaku fungsi survival yang menurun secara signifikan setelah waktu tertentu adalah sub bagian receptionist, confirmation, invoicing, customer notification dan delivery. Hal ini menunjukkan bahwa customer yang berada pada sub bagian tersebut akan memiliki peluang menunggu yang lebih lebih kecil setelah berada di proses tunggu yang relatif lebih singkat. Namun demikian, diantara keempat sub bagian tersebut, sub bagian receptionist merupakan bagian yang memiliki kecenderungan penurunan peluang fungsi survival waktu tunggu yang paling cepat. Sedangkan sub bagian delivery merupakan sub bagian dengan kecenderungan penurunan peluang fungsi survival waktu tunggu yang paling lambat. Selanjutnya, Sub bagian pelayanan program EM yang memiliki perilaku fungsi survival yang menurun secara eksponensial adalah sub bagian service, final inspection dan technical complete. Dengan demikian, peluang seorang customer yang berada pada ketiga sub bagian tersebut untuk tetap menunggu setelah menghabiskan waktu $t$ menit dalam proses tunggu akan semakin berkurang secara berlahan seiring bertambah lamanya waktu yang telah mereka habiskan dalam proses menunggu. Dengan kata lain, fungsi survival untuk ketiga sub bagian tersebut merupakan fungsi yang bergantung pada waktu $t$. Semakin lama waktu tunggu yang dihabiskan oleh customer pada program EM di PT. Dunia Barusa cabang Banda Aceh, maka nilai fungsi survival akan semakin mengecil.

Fungsi penting lain dalam analisis survival adalah fungsi hazard. Fungsi hazard pada waktu $t$ menjelaskan laju terjadinya kegagalan seketika pada saat $t$ menit dari seorang customer yang berada pada proses tunggu pelayanan program EM di PT. Dunia Barusa cabang Banda Aceh. Pengertian dari kegagalan dalam kasus ini adalah mulai dilayaninya customer tersebut pada sebuah sub bagian pelayanan program EM. Dengan kata lain, fungsi hazard menjelaskan laju dimulainya proses pelayanan seketika dari seorang customer yang berada dalam proses tunggu 


\section{Samsul Anwar, Tri Wahyudi, Mutia Andriani, Dinda Maulina, Juraida Fitri, Raihan Nora, Zulfazli}

pelayanan pada saat $t$ menit. Gambar 5 menampilkan visualisasi nilai fungsi hazard dari data lama waktu tunggu pada semua sub bagian pelayanan program EM di PT. Dunia Barusa cabang Banda Aceh.
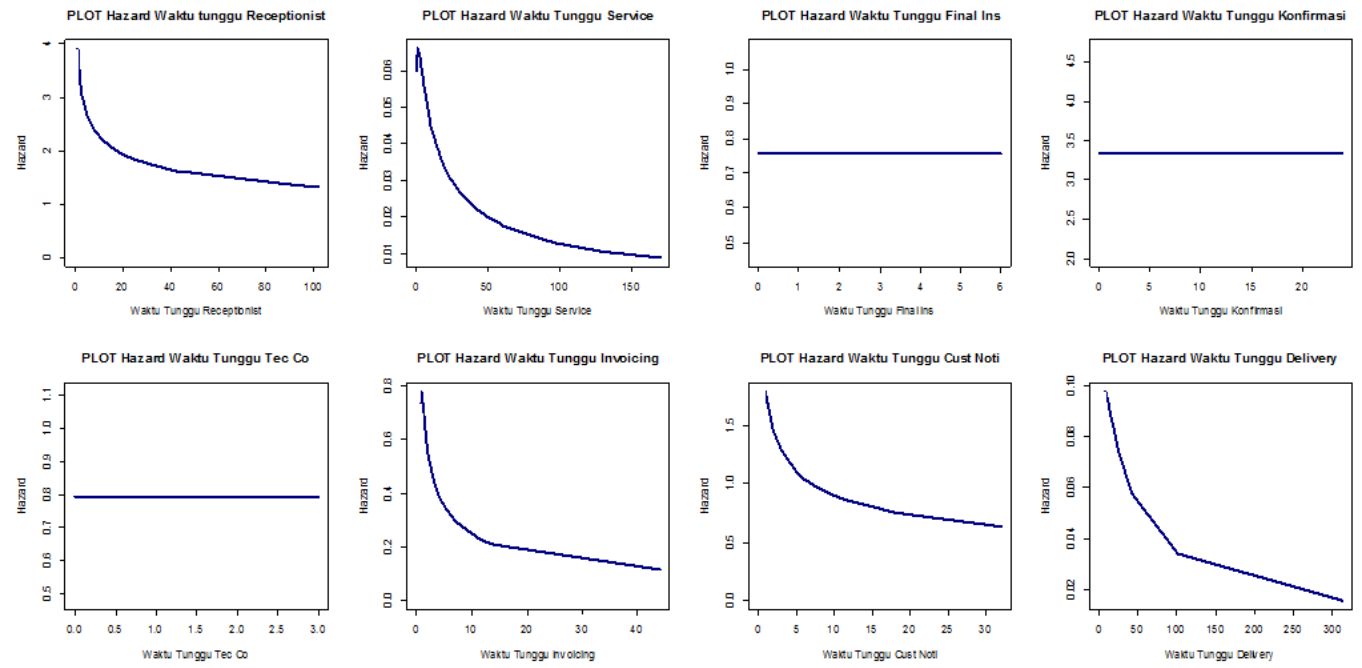

Gambar 5. Plot Nilai Hazard Data Lama Waktu Tunggu Pelayanan Program EM PT. Dunia Barusa Cabang Banda Aceh

Berdasarkan Gambar 5, terlihat bahwa perilaku fungsi hazard secara umum dapat dikelompokkan menjadi dua. Pertama, fungsi hazard yang cenderung mengalami penurunan nilai seiring bertambah lamanya waktu tunggu proses pelayanan program EM. Kedua, fungsi hazard yang tidak dipengaruhi oleh lamanya waktu tunggu program EM tersebut. Terdapat $5 \mathrm{sub}$ bagian yang memiliki fungsi hazard kelompok pertama, yaitu sub bagian receptionist, service, invoicing, customer notification dan delivery. Sedangkan sub bagian yang memiliki nilai hazard yang konstan terhadap waktu adalah sub bagian final inspection, confirmation dan technical complete. Dengan demikian, peluang seorang customer untuk mulai dilayani seketika pada sub bagian receptionist, service, invoicing, customer notification dan delivery cenderung akan semakin mengecil seiring bertambah lamanya waktu tunggu $t$. Diantara kelima sub bagian tersebut, sub bagian receptionist merupakan sub bagian yang memiliki nilai fungsi hazard yang relatif lebih besar dibandingkan dengan keempat sub bagian lainnya. Sedangkan diantara ketiga sub bagian yang memiliki nilai fungsi hazard yang konstan, sub bagian confirmation merupakan sub bagian dengan nilai hazard yang paling besar. Dengan kata lain, laju pelayanan seketika kepada customer yang paling besar berada pada sub bagian confirmation dan besarnya kelajuan tersebut tidak dipengaruhi oleh lamanya waktu tunggu seorang customer pada sub bagian tersebut. Sedangkan sub bagian yang memberikan pelayanan seketika yang paling kecil adalah sub bagian final inspection dengan nilai yang konstan tidak dipengaruhi oleh lama waktu tunggu di sub bagian tersebut.

\section{Kesimpulan}




\section{Samsul Anwar, Tri Wahyudi, Mutia Andriani, Dinda Maulina, Juraida Fitri, Raihan Nora, Zulfazli}

Perilaku waktu tunggu proses pelayanan program EM PT. Dunia Barusa cabang Banda Aceh dapat dilihat melalui empat fungsi dasar dalam analisis survival yaitu fungsi PDF, CDF, survival dan hazard. Fungsi PDF menggambarkan bahwa peluang seorang customer mendapatkan pelayanan pada program EM akan semakin kecil seiring bertambahnya lama waktu tunggu. Dengan kata lain, customer berpeluang besar untuk mendapatkan pelayanan program EM dengan proses tunggu yang relatif singkat. Disisi lain, fungsi CDF yang merupakan akumulasi peluang seorang customer mendapatkan pelayanan cenderung mendekati nilai 1 seiring bertambah lamanya waktu tunggu pada kedelapan sub bagian program EM tersebut. Berdasarkan fungsi survival, diketahui bahwa peluang seorang customer untuk tetap menunggu setelah menghabiskan waktu $t$ menit pada proses tunggu memiliki kesamaan trend dengan fungsi PDF. Fungsi hazard yang menggambarkan besarnya kelajuan seorang customer untuk segera mendapatkan pelayanan pada sub bagian receptionist, service, invoicing, customer notification dan delivery sangat dipengaruhi oleh lamanya waktu tunggu customer tersebut. Sedangkan pada sub bagian final inspection, confirmation dan technical complete, fungsi hazard bernilai konstan tidak dipengaruhi oleh lama waktu tunggu customer pada ketiga sub bagian program EM tersebut.

\section{Daftar Pustaka}

[1] Kuntari, B. D., Kumadji, S., \& Hidayat, K., 2016. Pengaruh Kualitas Pelayanan Terhadap Kepuasan dan Loyalitas Pelanggan (Survei Pada Pelanggan Bengkel PT Astra International Tbk - Daihatsu Malang). Jurnal Administrasi Bisnis, Vol. 36, No. 1, hal. 196-202.

[2] Anwar, S., Afriyani, A., Ula, P. S., Safriana, I., Fajri, I., \& Ariska, R., 2017. Visitor Behavior in the Library of Syiah Kuala University based on Their Visiting Time Duration. Eksakta: Jurnal Ilmu-Ilmu MIPA, Vol. 17, No. 2, hal. 119-136. https://doi.org/10.20885/eksakta.vol17.iss2.art4

[3] Kleinbaum, D. G., \& Klein, M., 2012. Survival analysis : a self-learning text, Third edition. Springer Science Business Media, Inc., New York.

[4] Anwar, S., Ahya, D., Afriyani, A., Nurhidayati, N., Ariska, R., Wahyudi, R., \& Iswani, N., 2017. Analisis Waktu Pelayanan Penerbitan Izin Gangguan (HO) Dinas Penanaman Modal dan Pelayanan Terpadu Satu Pintu (DPM PTSP) Kota Banda Aceh. Jurnal Matematika Integratif, Vol. 13, No. 2, hal. 133 142. https://doi.org/10.24198/jmi.v13.n2.12785.133-142

[5] Anwar, S., Salsabila, I., Sofyan, R., \& Amna, Z., 2019. Laki-Laki atau Perempuan, Siapa yang Lebih Cerdas dalam Proses Belajar? Sebuah Bukti dari Pendekatan Analisis Survival. Jurnal Psikologi, Vol. 18, No. 2, hal. 281-296. https://doi.org/10.14710/jp.18.2.281-296

[6] Anwar, S., Afriyani, A., Ahya, D., Nurhidayati, N., Iswani, N., Ariska, R., \& Wahyudi, R., 2017. Analisis Faktor yang Mempengaruhi Lama Waktu Pembayaran Angsuran Pertama Program ZIS Produktif Baitul Mal Aceh. STATISTIKA: Journal of Theoretical Statistics and Its Applications, Vol. 17, No. 2, hal. 53-61. https://doi.org/10.29313/jstat.v17i2.2697

[7] Collett, D., 2003. Modelling Survival Data in Medical Research, Second edition. Chapman and Hall, London. 


\section{Samsul Anwar, Tri Wahyudi, Mutia Andriani, Dinda Maulina, Juraida Fitri, Raihan Nora, Zulfazli}

[8] Lee, E. T., \& Wang, J. W., 2003. Statistical Methods for Survival Data Analysis, Third edition. John Wiley \& Sons Inc., New Jersey.

[9] Zacks, S., 1992. Introduction to Reliability Analysis: Probability Models and Statistical Methods. Springer, New York.

[10] Rausand, M., \& Høyland, A., 2004. System reliability theory: models, statistical methods, and applications, Second edition. John Wiley \& Son, Hoboken.

[11] Hogg, R. V., \& Tanis, E. A., 2010. Probability and statistical inference. Pearson Prentice Hall, New Jersey.

[12] Stasinopoulos, M., Rigby, B., \& Akantziliotou, C., 2007. Instructions on how to use the GAMLSS package in R, Second edition. Technical Report 01/08, STORM Research Centre, London Metropolitan University, London. 